The University of Maine

DigitalCommons@UMaine

2010

Nest-Site Selection and Nest Survival of the Rusty Blackbird: Does

Timber Management Adjacent to Wetlands Create Ecological

Traps?

Luke L. Powell

Thomas P. Hodgman

William E. Glanz

James D. Osenton

Caleb M. Fisher

Follow this and additional works at: https://digitalcommons.library.umaine.edu/bio_facpub

Part of the Natural Resources and Conservation Commons, and the Ornithology Commons

This Article is brought to you for free and open access by DigitalCommons@UMaine. It has been accepted for inclusion in Biology and Ecology Faculty Scholarship by an authorized administrator of DigitalCommons@UMaine. For more information, please contact um.library.technical.services@maine.edu. 


\title{
NEST-SITE SELECTION AND NEST SURVIVAL OF THE RUSTY BLACKBIRD: DOES TIMBER MANAGEMENT ADJACENT TO WETLANDS CREATE ECOLOGICAL TRAPS?
}

\author{
Luke L. Powell ${ }^{1,5}$, Thomas P. Hodgman ${ }^{2}$, William E. Glanz ${ }^{1}$, James D. Osenton ${ }^{3}$, And Caleb M. Fisher ${ }^{4}$ \\ ${ }^{1}$ School of Biology and Ecology, University of Maine, Orono, ME 04469 \\ ${ }^{2}$ Bird Group, Maine Department of Inland Fisheries and Wildlife, Bangor, ME 04401 \\ ${ }^{3}$ Department of Wildlife Ecology, University of Maine, Orono, ME 04469 \\ ${ }^{4}$ Sterling College, Craftsbury Common, VT 05827
}

\begin{abstract}
Animals are subject to ecological traps when anthropogenic changes create habitat that appears suitable but when selected results in decreased fitness. The Rusty Blackbird (Euphagus carolinus) breeds in boreal wetlands and has declined by $85-95 \%$ over the last half century. We studied nest-site selection and daily nestsurvival rate (DSR) of 43 Rusty Blackbird nests in northern New England and evaluated whether regenerating logged areas adjacent to wetlands created ecological traps. Although nesting adults avoided high-canopied forests and selected areas with dense balsam fir (Abies balasmea) 1 to $3 \mathrm{~m}$ high, those characteristics were not associated with DSR. Conversely, the frequency of speckled alder (Alnus incana) and sedges (Cyperaceae) in the nest plot varied with DSR, suggesting that the risk of predation of nests within wetlands was lower. DSR also varied with past logging; nests in plots not harvested recently were $2.3 \times$ more likely to fledge young than nests in plots harvested within 20 years. When logging extends to the edges of or into wetlands, the subsequent dense regenerating conifers appear to attract Rusty Blackbirds to nest closer to or within these human-altered uplands, exposing their nests to increased predation not typical of unaltered wetlands. Three surrogates for habitat preference did not differ by timber-management history, suggesting that the birds do not prefer habitats that increase their fitness. Rusty Blackbirds nesting in harvested wetlands may be subject to "equal preference" ecological traps, and we suggest that buffers $75 \mathrm{~m}$ wide around the perimeter of suitable wetlands should increase DSR.
\end{abstract}

Key words: $\quad$ boreal wetlands, ecological trap, Euphagus carolinus, forest fragmentation, nest-site selection, nest survival, Rusty Blackbird.

\section{Selección de Sitios de Nidificación y Supervivencia de Nidos de Euphagus carolinus: ¿El Manejo Forestal Adyacente a los Humedales Crea una Trampa Ecológica?}

Resumen. Los animales son sujeto de trampas ecológicas cuando cambios antropogénicos crean un hábitat que parece apropiado pero, al ser seleccionado, resulta en una disminución de la aptitud biológica. Euphagus carolinus se reproduce en humedales boreales y sus poblaciones han disminuido en un 85-95\% durante los últimos cincuenta años. Estudiamos la selección de sitios de nidificación y la tasa diaria de supervivencia (TDS) de 43 nidos de E. carolinus en el norte de Nueva Inglaterra y evaluamos si las áreas aprovechadas en recuperación adyacentes a los humedales generaron trampas ecológicas. Aunque los adultos que anidaban evitaron bosques de dosel alto y seleccionaron áreas densamente pobladas de Abies balasmea de 1 a $3 \mathrm{~m}$ de altura, estas características no estuvieron asociadas con la TDS. Por el contrario, la frecuencia de Alnus incana y de ciperáceas en la parcela del nido varió con la TDS, sugiriendo que el riesgo de depredación de los nidos dentro de los humedales era menor. La TDS varió también con los aprovechamientos antiguos; los nidos de las parcelas no cosechadas recientemente tuvieron una probabilidad 2,3 veces mayor de criar pichones que los nidos en parcelas aprovechadas hace 20 años. Cuando el aprovechamiento maderero se extiende a los bordes de los humedales o dentro de los mismos, la regeneración posterior de coníferas parece atraer a individuos de E. carolinus a nidificar más cerca o dentro de estas tierras altas alteradas por los humanos, exponiendo sus nidos a una depredación mayor, atípica en humedales inalterados. Tres indicadores de preferencia de hábitat demostraron no ser diferentes entre historias de manejo forestal, sugiriendo que las aves no prefieren habitats que incrementen su aptitud biológica. Los individuos de E. carolinus que nidifican en humedales aprovechados pueden ser sujeto de trampas ecológicas de "igual preferencia", y sugerimos que las zonas de amortiguamiento de $75 \mathrm{~m}$ de ancho alrededor del perímetro de los humedales adecuados deberían incrementar la TDS.

Manuscript received 30 July 2010; accepted 13 September 2010.

${ }^{5}$ Current address: School of Renewable Natural Resources, Louisiana State University, Baton Rouge, LA 70803.

E-mail: LPowe19@LSU.edu

The Condor, Vol. 112, Number 4, pages 800-809. ISSN 0010-5422, electronic ISSN 1938-5422. @ 2010 by The Cooper Ornithological Society. All rights reserved. Please direct all requests for permission to photocopy or reproduce article content through the University of California Press's Rights and Permissions website, http://www.ucpressjournals.com/ reprintInfo.asp. DOI: $10.1525 /$ cond.2010.100152 


\section{INTRODUCTION}

Animal behaviors that increase reproductive success are strongly favored by natural selection. Thus, nesting birds should respond to environmental cues that indicate the presence of habitat that maximizes nest survival (Martin 1998). Recently, ecologists have documented situations where an animal is attracted to habitat cues that ultimately result in reduced fitness compared to fitness in other available habitat, a phenomenon referred to as an "ecological trap" (Remes 2003, Lloyd and Martin 2005, Weldon and Haddad 2005). Ecological traps are of particular interest to wildlife managers because they can lead to population declines - even if the less suitable but preferred habitat represents a small proportion of the available landscape (Robinson et al. 1995, Delibes et al. 2001, Kokko and Sutherland 2001).

For unknown reasons, the Rusty Blackbird (Euphagus carolinus), a once abundant North American songbird, is declining dramatically: by $85-95 \%$ over the last half-century, with a particularly precipitous drop in the 1970s (Greenberg and Droege 1999, Niven 2004, Sauer et al. 2005). Rusty Blackbirds breed in remote wetlands within boreal landscapes (Avery 1995), and their decline has been documented repeatedly in portions of the breeding range where seemingly appropriate habitat remains. The best available evidence suggests that the southern boreal forest, a region of intensive timber harvest and management, is the region of greatest decline (Greenberg et al. 2011). Therefore, the possibility that timber management has reduced the quality of nesting habitat and perhaps created an ecological trap needs further investigation. After all, the term "ecological trap" was introduced to describe how an increase in edge habitat as a result of logging led songbirds to selectively nest in habitats that appeared suitable on the basis of evolved behavioral cues but resulted in increased rates of nest predation (Gates and Gysel 1978). We focus this study on populations of Rusty Blackbird in Maine and Vermont, at the southeast edge of the species' range, which has contracted to the northwest by $160 \mathrm{~km}$ since 1983 (Powell 2008).

Three conditions must be met to provide strong evidence of an ecological trap (Robertson and Hutto 2006): (1) individuals' fitness in two habitats must be unequal, (2) individuals must prefer one habitat over another (in a severe trap) or prefer both habitats equally (in an equal-preference trap), and (3) individuals' fitness in the preferred (or equally preferred) habitat must be lower. To address these three conditions and to fill a knowledge gap resulting from the lack of published quantitative studies of the species' requirements for breeding habitat (but see Matsuoka et al. 2010), we (1) identified habitat features associated with the Rusty Blackbird's nest-site selection at two spatial scales, (2) estimated daily nest-survival rate (DSR) and determined the habitat features associated with nest fate, and (3) used the data from (1) and (2) to evaluate the hypothesis that regenerating clear-cuts adjacent to wetlands are an ecological trap for nesting Rusty Blackbirds.

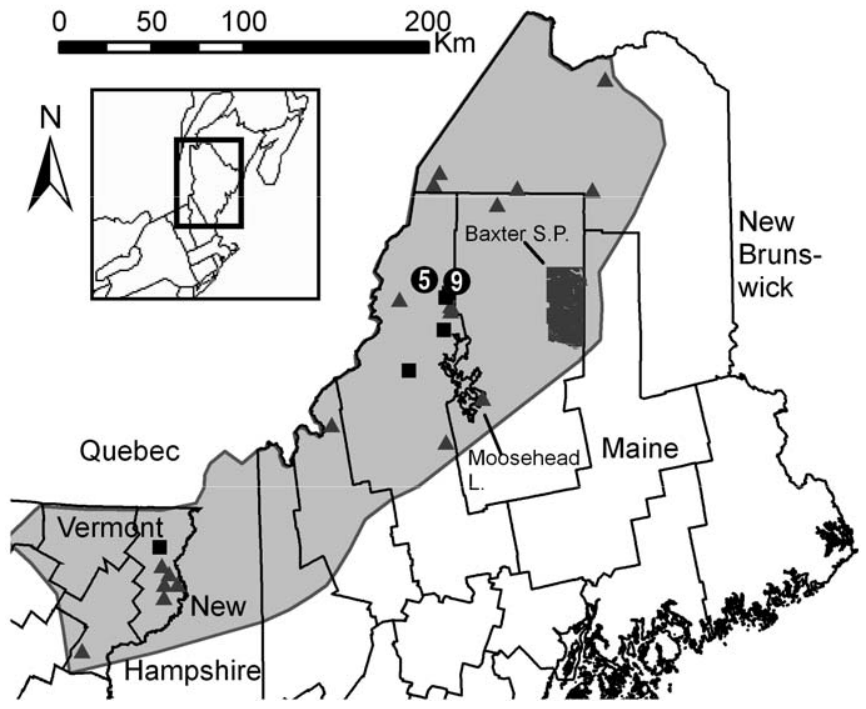

FIGURE 1. Rusty Blackbird nests found in Maine and Vermont, 2006-2008. Triangles represent sites with one nest, squares represent sites with two nests, and numbered circles represent sites with three or more nests. Light gray fill represents the extent of the Rusty Blackbird's known current breeding range in the continental United States (Powell 2008).

\section{METHODS}

\section{STUDY AREAS}

We conducted our study in northwestern Maine in May and June of 2006, 2007, and 2008 and in northeastern Vermont in May and June 2007 (Fig. 1). The landscape of northern Maine is relatively flat, uninhabited, and dominated by large-scale industrial timber management. Clear-cutting was widespread in this area during the 1970s and early 1980s in an effort to salvage timber killed during a spruce budworm (Choristoneura fumiferana) outbreak (Griffith and Alerich 1996). Although partial harvests became the primary method of logging after the Maine Forest Practices Act was implemented in 1991 (Maine Forest Service 1999, McWilliams 2005), regenerating clear-cuts covering dozens of hectares currently occupy a substantial portion of the landscape in our study area. Forested lands in western Maine and northeastern Vermont are similar; small-scale logging and rural communities perforate a landscape with considerably more topographic relief than northern Maine.

Rusty Blackbirds nest in or adjacent to swampy woodlands (Laughlin and Kibbe 1985), wooded fens (Avery 1995), bogs (Peterson 1988, Erskine 1992), damp swales with speckled alder (Alnus incana; Erskine 1992), and wetlands modified by beaver (Castor canadensis; Ellison 1990, Richards 1995). In New England, nest sites selected by Rusty Blackbirds are variable; the birds use conifers of short stature because of poor growing conditions (e.g., nutrient-poor peatlands), natural regrowth (e.g., wetlands modified then abandoned by 
beavers), or artificial regrowth (e.g., regenerating clear-cuts; Kennard 1920, Ellison 1990, Powell 2008). Common trees and understory plants include black spruce (Picea mariana), red spruce (P. rubens), balsam fir (Abies balsamea), quaking aspen (Populus tremuloides), paper birch (Betula papyrifera), red maple (Acer rubrum), speckled alder, Viburnum sp., heath shrubs (family Ericaceae), and Sphagnum spp. Potential nest predators we observed in the study areas included the Gray Jay (Perisoreus canadensis), Blue Jay (Cyanocitta cristata), American Crow (Corvus brachyrhynchos), and red squirrel (Tamiasciurus hudsonicus).

\section{SELECTION OF STUDY SITES}

As part of a concurrent study (Powell 2008), we surveyed for breeding Rusty Blackbirds at 561 wetlands throughout the species' breeding range in Maine and northeastern Vermont (Fig. 1) during May and June 2006, 2007, and 2008. We selected 353 wetlands on the basis of personal field experience or historical descriptions that suggested the presence of suitable habitat (Ellison 1990, Avery 1995), 196 wetlands with a geographically stratified random design, and 12 wetlands as the result of opportunistic roadside encounters of Rusty Blackbirds. In total, 544 wetlands (97\%) were within $50 \mathrm{~m}$ of roads and the remaining $17(3 \%)$ were between 100 $\mathrm{m}$ and $1 \mathrm{~km}$ of roads. Each survey included $3 \mathrm{~min}$ of passive observation followed by a 38 -sec broadcast of a male Rusty Blackbird's vocalization (recorded in New York State by Peter Kellogg, stored at Cornell Laboratory of Ornithology) and 5 min of post-broadcast observation.

\section{NEST MONITORING AND INDEX OF SITE FIDELITY}

After detecting one or more pairs of Rusty Blackbirds at a given wetland, we searched for nests and monitored nest success (Martin and Geupel 1993). For each nest found, we calculated fecundity by counting the number of eggs or nestlings, estimated the clutch or brood's age to within 2-3 days, calculated fledging dates and number of exposure days, and scheduled subsequent visits. We accessed most nests from the ground or a stepladder, but two (5.2 $\mathrm{m}$ and $8.8 \mathrm{~m}$ high) required climbing the nest tree itself. We determined a clutch's age by candling eggs (Lokemoen 1996) as described for the Red-winged Blackbird (Agelaius phoeniceus) and a brood's age by assessing nestlings' development (Balph 1975), as described for Brewer's Blackbird (Euphagus cyanocephalus). As active nests were often separated by large distances (Fig. 1), we checked nests approximately every 7 days to determine nest fate. We were careful to minimize disturbance (Martin and Geupel 1993), and we defined successful nests as those that fledged at least one nestling. In most instances, we confirmed success with observations of parents feeding fledglings. In a few instances, we considered the nest successful if there were no signs of predation and an abundance of white feather sheaths within the nest lining (T. Hodgman, pers. obs.).

\section{VEGETATION SAMPLING}

After the completion of each nest attempt, we used protocols modified from James and Shugart (1970) and Ellison (1990) to quantify the habitat in plots (5-m radius) around the nest and control points. To evaluate nest-site selection at two scales, between wetlands and within wetlands, we selected two control plots for each nest plot: one randomly placed plot at the nearest wetland ( $>1 \mathrm{~km}$ away) where we detected no Rusty Blackbirds (hereafter "outside control") and one randomly placed plot within the wetland containing the nest (hereafter "inside control"). To position inside control plots in wetlands with little or no open water (e.g., wooded bogs with wet pockets of Sphagnum spp.), we started at the nest tree (or for outside control plots, what we considered the center of the wetland), randomly selected a direction of travel, then walked $50 \mathrm{~m}$ in that direction. To position control plots in wetlands with ample open water, we used a different protocol because the above procedure often would have placed the control plot in open water. Therefore, we began at what we considered the center of the wetland, randomly selected a direction of travel and continued in that direction until the vegetation indicated that we had reached the wetland/upland interface. From there, we used a random-number table including integers -5 through 15 to select a point corresponding to a distance from $5 \mathrm{~m}$ outside to $15 \mathrm{~m}$ inside the wetland and perpendicular to the upland/wetland interface. From our randomly selected location, we centered all control plots on the nearest spruce or fir of size suitable for a nest (2-5 $\mathrm{m}$ tall; Avery 1995).

Within each 5-m-radius circular plot, we took measurements at 40 points, ten in each cardinal direction ("plot scale"; Table 1). We spaced points every $0.5 \mathrm{~m}$ along four $5-\mathrm{m}$ transects, each radiating from the plot's center in the four cardinal directions. At each point, we recorded the number of stems and the height (in 1-m interval classes below $5 \mathrm{~m}$ and in $5-\mathrm{m}$ height classes above $5 \mathrm{~m}$ ) of all vegetation, plus the presence or absence of mud and water in contact with a 7.6-cm-diameter pole. We used an ocular tube (James and Shugart 1970) to estimate the vegetation that the pole would have contacted if it was longer than $5 \mathrm{~m}$ and used a range finder to determine the height class of tall vegetation. Because we suspected the effects of canopy height extended beyond $5 \mathrm{~m}$ from nests, we used a range finder to measure maximum canopy height within $11 \mathrm{~m}$ of the plot's center (James and Shugart 1970). Within several sites, timber-harvest history was heterogeneous, so we described the history of logging at the plot scale as either (1) no evidence for $>20$ years (hereafter "no recent harvests") or (2) within 20 years (hereafter "recently harvested"). We estimated the number of years since the last harvest by counting the number of branch whorls on conifers of the youngest size class. We took additional measurements at the site scale and the microsite scale (Table 1). 
TABLE 1. Descriptions of variables used to (1) describe plots in which Rusty Blackbirds nested, (2) model nests' daily survival rate (DSR), (3) and compare plots by history of logging in northern New England, 2006-2008.

\begin{tabular}{|c|c|c|c|c|}
\hline \multirow[b]{2}{*}{ Variable } & \multirow[b]{2}{*}{ Description } & \multicolumn{3}{|c|}{ Analyses performed } \\
\hline & & Nest-plot selection & DSR & Logging \\
\hline YEAR & Year nest was active: 2006, 2007, or 2008 & & $x$ & \\
\hline \multicolumn{5}{|l|}{ Site scale } \\
\hline DIST_ROAD & Distance $(m)$ to the nearest road & & $x$ & \\
\hline DIST_UPLAND & $\begin{array}{l}\text { For nests in uplands, distance }(\mathrm{m}) \text { to the wetland/upland } \\
\text { interface. }\end{array}$ & & $x$ & $x$ \\
\hline \multicolumn{5}{|l|}{ Plot scale ${ }^{a}$} \\
\hline ALDERS & Frequency ${ }^{\mathrm{b}}$ of alder cover; wetland indicator & $x$ & $x$ & $x$ \\
\hline CANOPY_HT & Height $(\mathrm{m})$ of tallest tree within $11 \mathrm{~m}$ of nest & $x$ & $x$ & $x$ \\
\hline DIST_WATER & Distance $(\mathrm{m})$ from nest to standing water & & & $\times$ \\
\hline FIRS1-3M & Frequency ${ }^{\mathrm{b}}$ of fir cover $1-3 \mathrm{~m}$ high & $x$ & $x$ & $x$ \\
\hline MUD & Frequency of mud; wetland indicator & & & $x$ \\
\hline SPHAGNUM & Frequency of Sphagnum cover; indicator of acidic wetlands & $x$ & & \\
\hline SPRUCES1-3M & Frequency of spruce $1-3 \mathrm{~m}$ high & $x$ & & \\
\hline WATER & Frequency ${ }^{\mathrm{b}}$ of standing water; wetland indicator & $x$ & & $x$ \\
\hline SEDGES & Frequency ${ }^{\mathrm{b}}$ of sedge cover; wetland indicator & & $x$ & $x$ \\
\hline TIMBER_MGMT & $\begin{array}{l}\text { Binary variable describing whether the nest plot was located in } \\
\text { a stand logged within } 20 \text { years or within a plot that had not } \\
\text { been cut for }>20 \text { years }\end{array}$ & & $x$ & \\
\hline \multicolumn{5}{|l|}{ Microsite scale } \\
\hline NEST_TREE_AGE & $\begin{array}{l}\text { Age (year) of the tree that the nest was placed on, calculated } \\
\text { from a count of the number of branch whorls }\end{array}$ & & $x$ & $x$ \\
\hline NEST_TREE_DBH & Diameter at breast height $(\mathrm{cm})$ of the tree the nest was placed on & & & $x$ \\
\hline NEST_TO_GROUND & Distance $(\mathrm{cm})$ from the nest to the ground & & & $\times$ \\
\hline NEST_TREE_GENUS & Genus of the tree the nest was placed on (spruce or fir) & & $x$ & \\
\hline NEST_TREE_HT & Height $(\mathrm{m})$ of the tree the nest was placed on & & & $\times$ \\
\hline CONCEAL & $\begin{array}{l}\text { Minimum \% concealment of the nest among six measurements } \\
\text { taken } 1 \mathrm{~m} \text { away from the nest in the four cardinal directions, } \\
\text { from above, and from below }\end{array}$ & & $x$ & $x$ \\
\hline
\end{tabular}

${ }^{a}$ Within $5 \mathrm{~m}$ of the plot's center, except for CANOPY_HT, which was measured to within $11 \mathrm{~m}$.

${ }^{b}$ Frequency refers to the total number of times a given cover type was detected within each plot. At each point, presence/absence of each variable was recorded, except woody plants, for which the number of stems at each point was recorded.

\section{STATISTICAL ANALYSES}

Nest-plot selection. We modeled nest-plot selection by comparing nest and control plots at two different spatial scales, between and within wetlands. Using matched-pairs logistic regression, we compared each nest plot with both its betweenwetland and its within-wetland control plot. Prior to the analysis, we reviewed the literature and used our field experience to compile 22 variables that we considered plausible contributors to the Rusty Blackbird's nest-site selection. These variables fell into four general categories: spruce and fir density near the height of nests (Ellison 1990), alder density, canopy height/density, and indicators of the wetland's condition. To reduce the number of variables, we combined correlated variables where appropriate (e.g., frequency of firs 1 to $2 \mathrm{~m}$ high plus frequency of firs 2 to $3 \mathrm{~m}$ high; Spearman's rank correlation test, $r>0.5$ ) or retained the correlated variable most relevant to our hypotheses. Using the remaining six variables (Table 1), we ran 15 a priori models: six univariate models, one null model, and eight additive models in combinations that we considered biologically meaningful descriptors of Rusty Blackbird nesting habitat. For analyses both between and within wetlands, we assessed the relative fit of the same set of 15 candidate models with Akaike's information criterion corrected for small sample sizes (AICc; Burnham and Anderson 2002). We checked for interaction terms in two best-fit models and assessed goodness of fit with the varianceinflation factor from the global model.

Nest survival. We analyzed 40 nests to determine DSR; we excluded from our analyses one nest that may have never contained eggs and two nests that may have been abandoned because of disturbance during our attempts to capture the birds as part of our concurrent studies (Powell 2008). To test the hypothesis that Rusty Blackbirds select nest sites that are positively associated with DSR, we started our candidate set with the two most influential variables from the nest-site analysis, CANOPY_HT and FIRS1-3M. We then added eight variables that we considered ecologically plausible influences on DSR (Table 1). We formed 28 models total: 11 univariate 
models, a null model, 15 bivariate models, and one trivariate model based on combinations of nest, canopy, and vegetation variables that we considered ecologically plausible influences on DSR. We formed 24 of the 28 models a priori, then later added four a posteriori models that included an 11th variable, SEDGES, after we found that ALDERS, another wetland indicator, influenced DSR. We used $\mathrm{AIC}_{c}$ to rank each model's performance in program MARK (White and Burnham 1999).

When the nests in a given category have DSR $=1.0$ (i.e., no nests in the category failed), the usual methods for variance estimation are not appropriate (Aebischer 1999), and $\mathrm{DSR}=1.0$ for YEAR $=2006$ and TIMBER_MGMT $=$ no recent harvest. To account for this, we added an additional, fictitious, nest to the dataset (with YEAR $=2006$, TIMBER MGMT = no recent harvest) and "depredated" this nest after 23 days of exposure. For the other covariates of this fictitious nest, we used the mean values for nests with no recent harvest. We believe this represents a conservative approach, as we artificially raised the rate of nest predation above what we observed in the field.

We assessed the relative importance of each variable by summing the Akaike weights of each model that included that variable (Burnham and Anderson 2002); to reduce bias in this procedure, we included each variable in four models. As we recorded an average clutch size of $4.5 \pm 1.1 \mathrm{SE}$ and parents tend to begin incubation with the penultimate egg (Matsuoka et al. 2010), we used 4 days for the period of egg laying, 13 days for incubation, and 12 days for the nestling period for a total of 29 exposure days. We thus calculated nest success with the model-averaged DSRs (Burnham and Anderson 2002) as $\mathrm{DSR}^{29}$ (Klett et al. 1986).

Comparing timber-management histories. To examine differences between nests in plots with no recent harvests and in those recently harvested, we tested relevant variables from the plot scale and microsite scale (Table 1) for normality (Shapiro-Wilk $W, P<0.05$ ) and equality of variances
(Levene's tests, $P<0.05$ ), then transformed nonparametric variables as needed and ran Student's $t$-tests on the normally distributed variables. When transformed variables failed to meet the normality assumption of $t$-tests, we ran nonparametric unpaired Mann-Whitney $U$-tests.

Other than the nest-survival analysis in MARK, we performed all statistical analyses in Program R (R Development Core Team 2008). We present means and parameter estimates $\pm 1 \mathrm{SE}$, considered probability tests significant at $\alpha<0.1$, and considered models with $\Delta \mathrm{AIC}<2.0$ as those with substantial support (Burnham and Anderson 2002). When more than one model containing a given variable received substantial support, we present model-averaged parameter estimates and DSRs (Burnham and Anderson 2002).

\section{RESULTS}

\section{NESTING ECOLOGY}

We found 43 Rusty Blackbird nests, 7 in 2006, 28 in 2007, and 8 in 2008 (Fig. 1). Rusty Blackbirds placed their nests in black or red spruce $(n=23)$, balsam fir $(n=16)$, white spruce $(n=2)$, northern white cedar, $(n=1)$ and a Viburnum shrub $(n=1)$. Median age of the primary nest tree was 14 years $(\bar{x}=17.87 \pm$ $1.46 \mathrm{yrs}$, range $8-50)$. All nests were within $75 \mathrm{~m}$ of standing water $(\bar{x}=12.07 \pm 3.04 \mathrm{~m}$, range $0-71) ; 29$ nests were within wetlands, and the 14 nests found in uplands averaged $7.25 \pm$ $3.01 \mathrm{~m}$ (range 0.3-95) from the wetland/upland interface.

\section{NEST-PLOT SELECTION}

Both between and within wetlands, the best-fit model describing Rusty Blackbird nest-site selection included CANOPY_HT (between wetlands: $\beta=-0.349 \pm 0.078$; within wetlands: $\beta=$ $-0.183 \pm 0.072$ ) and FIRS1 $-3 \mathrm{M}$ (between wetlands: $\beta=0.104 \pm$ 0.034; within wetlands: $\beta=0.039 \pm 0.072$; Table 2), indicating that Rusty Blackbirds selected for short canopies with dense cover of pole-stage firs. CANOPY_HT was included in the three best-fit models at both scales, and no other models received

TABLE 2. Three best-fit models, by Akaike's information criterion ( $\left.\mathrm{AIC}_{c}\right)^{\mathrm{a}}$, predicting differences between 5-m-radius plots centered on a Rusty Blackbird nest $(n=43)$ and randomly placed control plots at two spatial scales in northern New England, 2006-2008.

\begin{tabular}{|c|c|c|c|c|c|c|c|c|}
\hline \multirow[b]{2}{*}{ Model $^{\mathrm{b}}$} & \multicolumn{4}{|c|}{ Between wetlands } & \multicolumn{4}{|c|}{ Within wetlands } \\
\hline & $\begin{array}{c}-2 \log \\
\text { (likelihood) }\end{array}$ & $K$ & $\Delta \mathrm{AIC}_{c}^{\mathrm{c}}$ & $w_{i}$ & $\begin{array}{c}-2 \log \\
\text { (likelihood) }\end{array}$ & $K$ & $\Delta \mathrm{AIC}_{c}{ }^{\mathrm{c}}$ & $w_{i}$ \\
\hline CANOPY_HT + FIRS1-3M & 41.0 & 4 & 0.00 & 0.69 & 53.9 & 4 & 0.00 & 0.57 \\
\hline CANOPY_HT + FIRS1-3M + SPRUCES1-3M & 40.8 & 5 & 1.59 & 0.31 & 53.9 & 5 & 2.32 & 0.18 \\
\hline CANOPY_HT & 49.6 & 3 & 14.75 & 0.00 & 56.9 & 3 & 3.74 & 0.09 \\
\hline Null & 59.6 & 2 & 32.43 & 0.00 & 59.6 & 2 & 6.96 & 0.02 \\
\hline
\end{tabular}

${ }^{\mathrm{a}} K$, number of parameters; $\mathrm{AIC}_{c}$, AIC adjusted for small sample size; $\Delta \mathrm{AIC}_{c}$, difference in $\mathrm{AIC}_{c}$ relative to the most parsimonious value; $w_{i}$, Akaike weight.

${ }^{\mathrm{b}}$ This table excludes 11 models that received little support $\left(\Delta \mathrm{AIC}>5.9, w_{i}<0.05\right)$.

${ }^{\mathrm{c}} \mathrm{AIC}_{c}$ value of the best-fit between-wetlands model: 91.0 , within-wetlands: 116.4; variance-inflation factor ( $\left.\hat{c}\right)$ for global model between wetlands: 1.02 , within wetlands: 1.33 . 
substantial support $\left(\triangle \mathrm{AIC}_{c}>5.9\right)$. Adding SPRUCES1-3M (between wetlands: $\beta=0.024 \pm 0.038$; within wetlands: $\beta=$ $0.001 \pm 0.018)$ to the best-fit model decreased the fit at both scales (Table 2). Our analyses provided no substantial evidence that variables representing wetland conditions (WATER, ALDERS, SPHAGNUM) influenced nest-site selection; no other models including those variables received substantial support at either scale $\left(\Delta \mathrm{AIC}_{c}>5.9\right)$.

\section{NEST SURVIVAL}

All 14 nests that failed were located in plots harvested within the previous 20 years. We concluded that 11 nests were depredated, as all eggs or chicks were destroyed or disappeared prior to the estimated date of fledging, while three nests were abandoned. We did not observe evidence of brood parasitism, nor did we detect Brown-headed Cowbirds (Molothrus ater) in our study areas; we documented only two addled eggs. In our original nest-survival analysis preceding the addition of the fictitious nest, the three best-fit models predicting DSR were TIMBER_MGMT + YEAR $\left(\right.$ AIC $\left._{c}=60.1\right)$, TIMBER_MGMT + $\operatorname{ALDERS}\left(\Delta \mathrm{AIC}_{c}=0.2\right)$ and TIMBER_MGMT $\left(\Delta \mathrm{AIC}_{c}=1.9\right)$, respectively. No other model received substantial support $\left(\Delta \mathrm{AIC}_{c}>3.8\right)$, and the null model received essentially no support $\left(\Delta \mathrm{AIC}_{c}=8.7\right)$.

Predictably, the addition of the fictitious depredated nest (no recent harvest, YEAR $=2006$ ) shifted the relative importance of the models (Table 3 ). The five models receiving substantial support included combinations of ALDERS, TIMBER_MGMT, SEDGES, and TREE_AGE, with ALDER included in each of the four best-fit models. When we averaged the Akaike weights $\left(w_{i}\right)$ of each variable across all the

TABLE 3. Result of model selection by Akaike's information criterion (AIC) a for survival of Rusty Blackbird nests $(n=40)$ in northern New England, 2006-2008. ${ }^{\mathrm{b}}$

\begin{tabular}{lcccc}
\hline \hline Model & $\begin{array}{c}-2 \log \\
\text { (likelihood) }\end{array}$ & $K$ & $\Delta \mathrm{AIC}_{c}{ }^{c}$ & $w_{i}$ \\
\hline SEDGES + ALDERS & 68.6 & 3 & 0.00 & 0.15 \\
TIMBER_MGMT + ALDERS & 68.7 & 3 & 0.08 & 0.14 \\
ALDERS & 70.8 & 2 & 0.20 & 0.13 \\
ALDERS + NEST_TREE_AGE & 69.3 & 3 & 0.72 & 0.10 \\
TIMBER_MGMT & 72.0 & 2 & 1.34 & 0.08 \\
SEDGES & 73.0 & 2 & 2.35 & 0.05 \\
NEST_TREE_AGE & 73.3 & 2 & 2.65 & 0.04 \\
Null & 75.3 & 1 & 2.70 & 0.04 \\
\hline
\end{tabular}

${ }^{\mathrm{a}} K$, number of parameters; $\mathrm{AIC}$, AIC adjusted for small sample size; $\Delta \mathrm{AIC}_{c}$, difference in $\mathrm{AIC}_{c}$ relative to the most parsimonious value; $w$, Akaike weight.

${ }^{\mathrm{b}}$ This table excludes 20 models that received less support than the null model. The table describes the results after the addition of a fictitious, depredated nest to the uncut treatment as described in methods. ${ }^{c}$ AIC value of the best-fit model = 74.6; of global model $=1.57$. ${ }^{\mathrm{d}}$ SEDGES was added a posteriori. candidate models, the most influential variables, ordered in decreasing order of importance, were ALDERS $\left(\Sigma w_{i}=0.53\right)$, TIMBER_MGMT $\left(\Sigma w_{i}=0.23\right)$, SEDGES $\left(\sum w_{i}=0.22\right)$, and NEST_TREE_AGE $\left(\Sigma w_{i}=0.16\right)$; no other variable received more than $\Sigma w_{i}=0.07$-including YEAR $\left(\Sigma w_{i}<0.02\right)$. Two variables indicating wet conditions, ALDERS $(\beta=0.113 \pm$ $0.089)$ and SEDGES ( $\beta=0.082 \pm 0.076)$, were positively correlated with DSR. Consistent with our original analysis, DSR was higher for nests in plots with no recent harvests (DSR $=$ $0.990 \pm 0.010,114$ exposure days, estimated nest success $=$ $76 \%, n=10)$ than in recently harvested plots (DSR $=0.963 \pm$ $0.012,309$ exposure days, estimated nest success $=33 \%, n=$ $30)$; accordingly, DSR was positively correlated with NEST_ TREE_AGE $(\beta=0.052 \pm 0.049)$. Again as in our original analysis, we found no substantial support for models that included CANOPY_HT or FIRS1-3M-the best predictors of nest-plot placement $\left(\Delta \mathrm{AIC}_{c}>4.2 ; \Sigma w_{i}<0.02\right)$. Averaged among the five models with substantial support, DSR for all 40 nests was $0.983 \pm 0.008$, (estimated nest success $=61 \%$, 423 exposure days).

\section{COMPARING TIMBER-MANAGEMENT HISTORIES}

In plots with no recent harvests, only two of 10 nests (20\%) were placed in uplands (mean distance $4.0 \pm 3.0 \mathrm{~m}$ ), while 12 of 33 nests (36\%) at recently harvested sites were placed in uplands (mean distance $21.7 \pm 7.9 \mathrm{~m}$ ). Furthermore, nests in plots with no recent harvests were closer to standing water (2.04 \pm $0.87 \mathrm{~m})$ than were nests at recently harvested sites (15.05 \pm $\left.1.13 \mathrm{~m} ; t_{28}=3.48, P=0.002\right)$. When we examined indicators of wetland conditions, we found that nest plots with no recent harvests contained more WATER (no recent harvest, $8.7 \pm$ 2.9; recently harvested, $3.3 \pm 1.1 ; U=93, P=0.03$ ), MUD (no recent harvest, $4.5 \pm 1.6$; recently harvested, $0.8 \pm 1.1 ; U=94$, $P=0.014$ ), and SEDGES (no recent harvest, $5.0 \pm 1.3$, recently harvested, $2.6 \pm 0.7 ; U=72.5, P=0.005)$, although ALDERS did not differ by logging history (no recent harvest, $6.4 \pm 2.3$; recently harvested, $6.9 \pm 2.7 ; U=119.5, P=0.16$ ).

Variables associated with nest-plot placement did not vary with logging history (FIRS1-3M: no recent harvest = $17.9 \pm 3.1$, recently harvested $=19.4 \pm 3.4, t_{41}=0.06, P=0.56$; CANOPY_HT: no recent harvest $=7.8 \mathrm{~m} \pm 0.4$, recently harvested $\left.=7.6 \mathrm{~m} \pm 0.4, t_{41}=-0.85, P=0.40\right)$. Although NEST TREE_AGE was predictably less in plots that had been recently harvested (no recent harvest, $28.0 \pm 4.6$; recently harvested, $\left.14.9 \pm 0.7, t_{9}=-2.82, P=0.02\right)$, no other microsite variables differed by logging history (CONCEAL: no recent harvest $=34.4 \pm 3.8$, recently harvested $=38.7 \pm 4.3, U=$ 220.5, $P=0.091$; NEST_TO_GROUND: no recent harvest $=$ $2.3 \pm 0.8$, recently harvested $=1.5 \pm 1.1, t_{41}=-1.50, P=0.14$; NEST_TREE_HT: no recent harvest $=3.6 \pm 0.8$, recently harvested $=3.5 \pm 1.2, t_{41}=0.17, P=0.86$; NEST_TREE_DBH: no recent harvest $=5.2 \pm 2.0$, recently harvested $=4.6 \pm 1.2$, $\left.t_{10}=0.53, P=0.61\right)$. 


\section{DISCUSSION}

Animals are subject to ecological traps when anthropogenic changes create habitat that appears suitable, yet when preferred and subsequently selected, results in decreased fitness. Here we discuss the Rusty Blackbird's nest-site selection in a historical and current perspective. We argue that the availability of nesting habitat has increased with largescale logging, which has created an incongruence between nest-site selection and nest survival. Finally, we frame our findings in terms of Robertson and Hutto's (2006) three conditions necessary to demonstrate an ecological trap and discuss additional data that address habitat preference rather than selection.

\section{NEST-PLOT SELECTION: PRESENT AND PAST}

Both within and between wetlands, we found that nesting Rusty Blackbirds avoid tall canopies, select plots with dense growth of firs from 1 to $3 \mathrm{~m}$ high, and place nests in short conifers that average less than 18 years old. Similarly, Ellison (1990) found that in Vermont, nests were associated with coniferous regeneration and thick cover from 2 to $4 \mathrm{~m}$ high. Across the boreal forest, Matsuoka et al. (2010) found that Rusty Blackbirds are most likely to nest in conifers (nest height $\bar{x}=1.6$ ) in all regions but interior Alaska, where they nest in what is available - deciduous shrubs. Thick coniferous growth provides relatively dense foliage at nest height $(\bar{x}=$ $1.7 \mathrm{~m}$ in our study), presumably to conceal nests from predators. Rusty Blackbirds clearly select for nest sites in areas of dense coniferous growth and undoubtedly did so before the appearance of humans in the boreal forest. Historical nesting sites likely included bogs and fens with naturally stunted coniferous growth, as well as coniferous regeneration resulting from irregular forest fires and blow-downs adjacent to wetlands. Beavers may benefit the Rusty Blackbird by providing disturbed yet relatively unfragmented nesting habitat, as they selectively remove hardwoods, increasing light gaps and encouraging coniferous regeneration on a local scale (Johnson and Naiman 1990).

Although Rusty Blackbirds are attracted to disturbed sites that support dense young coniferous growth, it seems unlikely that historical disturbances approached the current spatial scale of anthropogenic disturbance from timber harvesting. During the 20th century, landscape-scale anthropogenic changes (e.g., clear-cutting, fire suppression) led to increasingly destructive outbreaks of the spruce budworm in the coniferous forests of northeastern North America, with those of 1910-1920, 1945-1955, and 1968-1985 defoliating 10, 25, and 55 million ha, respectively (Blais et al. 1981, Blais 1983, 1985, Hardy et al. 1983). In Maine (Griffith and Alerich 1996) and elsewhere, extensive post-budworm salvage cutting followed these outbreaks, creating a superabundance of evenaged coniferous regrowth, attractive nesting habitat for Rusty
Blackbirds. Already vulnerable to the spruce budworm, dense stands of riparian conifers were hit particularly hard by the budworm and post-budworm salvaging because buffers preventing spraying were imposed to protect water bodies from the effects of pesticides (Irland 1988).

\section{NEST SURVIVAL}

Contrary to what one might expect if nest-site selection is adaptive, the variables associated with DSR differed substantially from those that nesting Rusty Blackbirds selected. Canopy height and fir density at nest height were poor predictors of nest fate, while timber-management history and alder and sedge density were the best predictors of DSR. We attributed 11 of the 14 nest failures to predation (the other three failed nests were abandoned); all of these were in sites cut $<20$ years earlier. Even after we added a fictitious depredated nest to the category of no recent harvest, nests in that category were still $2.3 \times$ more likely to fledge young than those in plots logged $<20$ years earlier. This difference between habitats in nest success (a component of fitness) meets the first of three conditions necessary to demonstrate an ecological trap (Robertson and Hutto 2006).

Predictably, nest-tree age also was positively correlated with DSR, suggesting that nests in older trees were more likely to fledge young. DSR varied with the frequency of alder and sedges, suggesting that nests within wetlands are less likely to suffer depredation. Nest plots in recently harvested sites had less water, less mud, and fewer sedges; nests in recently harvested sites were also farther into uplands than nests at sites not recently logged. When logging extends to the edges of or into wetlands, the resulting regeneration of conifers probably attracts Rusty Blackbirds to nest closer to or farther into uplands, exposing nests to increased predation pressure. Therefore, the cues that Rusty Blackbirds use to select nest sites may be maladaptive when habitat within or adjacent to wetlands is logged. Nests in recently harvested plots were placed in trees younger than in those with no recent harvest, but other than nest-tree age and the nest's position relative to wetlands, characteristics (CANOPY_HT, FIRS1-3M, CONCEAL, NEST_ TO_GROUND, NEST_TREE_HT, and NEST_TREE_DBH of nests) in the two categories of timber-management history were indistinguishable. This suggests that Rusty Blackbirds have not evolved to perceive cues that logged uplands are relatively risky places in which to nest.

The Gray Jay, Blue Jay, and American Crow were among the avian nest predators in our study areas, and the latter two tend to be more abundant in fragmented habitats (Robinson et al. 1995). Using 954 artificial nests in southeast Alaska, DeSanto and Willson (2001) never detected jays or red squirrels in open wetlands and found that nest-predation rates in regenerating clear-cuts $15-20$ years old (58\% of nests depredated), wetland edges (40\%), and wetland openings $(20 \%)$ differed. Robertson and Hutto (2007) found that Olive-sided Flycatchers 
(Contopus cooperi) prefer selectively harvested over naturally burned forest, despite higher rates of nest predation in the human-altered landscape. In regenerating clear-cuts in eastern Maine, Rudnicky and Hunter (1993) documented that depredated nests differed from undisturbed nests only in the increased cover of pole-stage conifers ( $0-3 \mathrm{~m}$ tall). They suggested that to avoid predation themselves, small nest predators (i.e., the red squirrel) may remain close to dense cover, where they are more likely to find nests in young stands with thick cover that are less voluminous and less structurally complex than mature stands.

\section{EVIDENCE FOR AN ECOLOGICAL TRAP}

Rusty Blackbird nests in stands with no recent harvests were more than twice as likely to fledge young than nests at sites logged within the past 20 years, so the first of three conditions necessary to demonstrate an ecological trap (Robertson and Hutto 2006) is met. To satisfy the other two conditions, the data must show equal preference for both habitats (an equal-preference trap) or preference for the less favorable habitat over the other (a severe trap) and higher fitness in the nonpreferred habitat. We found strong evidence that Rusty Blackbirds select for nest sites with a high density of polestage firs - the typical condition in regenerating logged boreal forest. However, nonrandom habitat use (e.g., nest-site selection) is not necessarily a suitable surrogate for preference (Van Horne 1983). For example, subordinate individuals can be found in nonpreferred habitat if they are excluded by dominant individuals (Sherry and Holmes 1988).

Therefore, in a post hoc effort to determine if Rusty Blackbirds not only select for but prefer the habitat in which their fitness suffers, we examined three surrogates for habitat preference (Robertson and Hutto 2006): year-to-year site fidelity, clutch size, and variation in year-to-year occupancy. Robertson and Hutto (2006) argued that year-to-year site fidelity is a useful surrogate for preference because individuals claiming territories in preferred habitat have the greatest site fidelity and lowest emigration rates (e.g., Sergio and Newton 2003). To estimate the Rusty Blackbird's year-to-year site fidelity, we searched for breeding pairs for at least $2 \mathrm{hr}$ during mid-May at all sites with nesting pairs in previous years. We had only four sites with banded birds, so we calculated species-level fidelity rather than individual fidelity. We argue that if individual preference is repeated across the landscape, species-level site fidelity should be higher in preferred nesting habitats. We found that year-to-year nest-site fidelity was no different at sites that had been recently harvested ( 8 of 14 returned) than at sites with no recent harvest ( 3 of 6 returned; $\chi_{1}^{2}=0.04, P=0.85$ ). Moreover, we documented five cases in which timber management adjacent to wetlands was heterogeneous (i.e., the site included both clear-cut and unlogged patches), yet Rusty Blackbirds nested in the regenerating clear-cuts in all five cases - presumably because they preferred regenerating conifers (L. L. Powell, pers. obs.).
The distribution of dominant individuals among habitat types can also imply preference (e.g., Davies 1992, Robertson and Hutto 2006), so, assuming that dominant individuals have larger clutches, we used clutch size to explore possible differences in habitat preference. Clutches in plots with no recent harvest were no larger $(4.4 \pm 0.3)$ than in recently harvested plots $(4.5 \pm 1.1$; Mann-Whitney $U=98.5, P=0.91$, $n=32$ nests), providing no evidence for the unequal distribution of dominant individuals or a particular habitat preference. Finally, temporal variation in population size can serve as a surrogate for preference (Robertson and Hutto 2006), as poorquality habitats can fluctuate in population size and "buffer" population fluctuations in relatively stable high-quality habitats (Kluyver and Tinbergen 1953, Brown 1969, O’Connor 1981, Gill et al. 2001). After surveying more than 700 wetlands in Maine and Vermont in 2001, 2002, 2006 and 2007, we found no evidence that variance in wetland occupancy varies with timber-management history (L. Powell, unpubl. data), again providing no evidence for a particular habitat preference. None of these surrogates for preference suggests that Rusty Blackbirds prefer habitats that maximize their fitness, suggesting an "equal preference" ecological trap (Robertson and Hutto 2006).

Because Rusty Blackbirds are sparsely distributed even in the core of their breeding range (Flood 1978, Avery 1995), large-scale timber harvesting across northeastern North America may have been especially damaging. Ecological traps may trigger the Allee effect at low population densities (i.e., reduced reproduction or survival), because with little intraspecific competition, individuals are relatively free to act on their (now maladaptive) preferences (Kokko and Sutherland 2001). Given the synchrony of the species' range contraction in Maine (Powell 2008), its sharp rangewide population decline (Greenberg and Droege 1999), and the most recent spruce budworm outbreak, we believe that large-scale reduction of DSR in logged forest may have contributed to the population decline and range contraction of the Rusty Blackbird in northeastern North America.

\section{FUTURE RESEARCH NEEDS}

Although we suspect that red squirrels and jays are the primary predators of Rusty Blackbird nests, this hypothesis should be tested with motion-detecting cameras. Furthermore, the overall nest success we recorded (61\%) is similar to levels found in Alaska (56\%; Matsuoka et al. 2010), but we have little data on fitness at other life-history stages with which to understand the stage(s) driving population declines. Studies of nest survival provide valuable information, yet they evaluate only one component of fitness. For example, although nesting Whitethroated Robins (Turdus assimilis) prefer forest fragments to coffee plantations despite higher nest predation in the fragments (Sekercioglu 2007), fledglings' survival was relatively high in the forest fragments, which mitigated the effects of low DSR and thus nullified the potential ecological trap (C. H. 
Sekercioglu, unpubl. data). To understand the interaction between logging and Rusty Blackbird fitness on the breeding grounds, DSR and survival of fledglings and juveniles must be studied at multiple spatial scales and under a variety of timbermanagement schemes, ideally in manipulative studies.

\section{MANAGEMENT IMPLICATIONS}

Regardless of whether Rusty Blackbirds are suffering from ecological traps on a large scale, we demonstrated relatively low DSR at recently logged sites (33\% vs. $76 \%$ in plots with no recent harvest), and showed that DSR increased with alder and sedge density, indicators of wetlands. We thus expect that the establishment of buffer zones of no logging around the perimeter of wetlands would increase the DSR of Rusty Blackbird nests. However, upland buffers will not reduce disturbance to the species entirely unless they are wide enough to (1) reduce predation via edge effects and (2) prevent Rusty Blackbirds from nesting in regenerating conifers in the uplands and simply flying across thin strips of mature forest to forage in wetlands.

Rusty Blackbird nests are almost always placed near water (Kennard 1920, Avery 1995, Matsuoka et al. 2010), which could work to their advantage, as even small forest fragments in Maine are less subject to nest predation if they are adjacent to water (Small and Hunter 1988). The 14 nests we found in uplands averaged $19.2 \pm 7.0 \mathrm{~m}$ away from wetlands, with the three farthest located 32, 48, and $95 \mathrm{~m}$ away. In two cases, Rusty Blackbirds nested in regenerating clear-cuts in the upland yet regularly flew over modest unlogged buffers $(<30 \mathrm{~m})$, presumably to feed in nearby wetlands (L. L. Powell, pers. obs.). For birds in general, predation rates are highest within $50 \mathrm{~m}$ of edges (Paton 1994), and in Maine, Vander Haegen and Degraaf (1996) found the effects of predation on artificial nests to extend $75 \mathrm{~m}$ into riparian buffers. Therefore, we suggest an unlogged buffer of $75 \mathrm{~m}$ around the perimeter of wetland occupied by or suitable for the Rusty Blackbird. Given the extensive literature on nest predation near edges and an improved understanding of breeding Rusty Blackbirds' use of space, 75-m buffers will likely increase nest survival in managed landscapes, although they may have limited utility for protecting habitat for foraging (Powell et al. 2010). Wetlands suitable for nesting are generally larger than 0.5 ha, are surrounded by softwoods, and feature pools of shallow water available as foraging substrate (Powell 2008). Thorough protection of such sites from disturbance will be difficult without a detailed understanding of the species' use of space (Powell et al. 2010), its social organization (Powell et al., in press), and the value of different types of foraging substrates. Management designed to improve young Rusty Blackbirds' survival rates could help prevent further population decline and range contraction. However, effective strategies to protect breeding Rusty Blackbirds in actively managed forests such as those in the Northeast will require close working relationships between land managers and conservation agencies, and the best possible data to guide them.

\section{ACKNOWLEDGMENTS}

We thank R. T. Jones and C. Holmberg for their tireless work as field technicians in 2007. We are grateful to W. Halteman for his statistical guidance and to S. T. Edmonds, D. M. "That Feeling" Ellis, N. Hazlet, T. U. Powell, M. D. Twine and B. Tyne and for their contributions in the field. The Maine Warden Service, Pittston Farms, S. and B. Foley, and Butch and company at Russell Pond Bear Hunting Camp provided critical logistical support. We thank R. L. Holberton, R. Greenberg, A. M. Januzzi, C. S. Loftin, C. Rimmer, M. Schlesinger, one anonymous reviewer, and particularly S. M. Matsuoka for perceptive comments on earlier drafts. This project was carried out in association with the International Rusty Blackbird Working Group and funded by the Maine Department of Inland Fisheries and Wildlife, Federal Aid in Wildlife Restoration, the U.S. Fish and Wildlife Service Region 5, the Maine Outdoor Heritage Fund, and the University of Maine graduate student government.

\section{LITERATURE CITED}

AEBISCHER, N. 1999. Multi-way comparisons and generalized linear models of nest success: extensions of the Mayfield method. Bird Study 46 Supplement:S120-138.

Avery, M. L. 1995. Rusty Blackbird (Euphagus carolinus), no. 200. In F. B. Gill and A. Poole [EDS.], The birds of North America. Academy of Natural Sciences, Philadelphia.

BALPH, M. H. 1975. Development of young Brewer's Blackbirds. Wilson Bulletin 87:207-230.

Blais, J. R., E. G. Kettela, And B. H. Moody. 1981. History of spruce budworm outbreaks in eastern North America with special reference to Newfoundland, p. 12-17. In J. Hudak and A. G. Raske [EDS.], Review of the spruce budworm outbreak in Newfoundland: its control and forest management implications. Newfoundland Forest Research Centre, St. John's, Newfoundland.

Blais, J. R. 1983. Trends in the frequency, extent, and severity of spruce budworm outbreaks in eastern Canada. Canadian Journal of Forest Research 13:539-547.

BLAIS, J. R. 1985. The ecology of the eastern spruce budworm: a review and discussion, p. 49-59. In C. J. Sanders, R. W. Stark, E. J. Mullins, and J. Murphy [EDS.], Recent advances in spruce budworm research. Proceedings of the CANUSA Spruce Budworm Symposium. Canadian Forestry Service, Ottawa.

BRown, J. L. 1969. The buffer effect and productivity in tit populations. American Naturalist 103:347-354.

Burnham, K. P., And D. R. Anderson. 2002. Model selection and multimodel inference: a practical information-theoretic approach, 2nd edition. Springer-Verlag, New York.

DAVIES, N. B. 1992. Dunnock behaviour and social organization. Cambridge University Press, Cambridge, UK.

De SAnto, T. L., AND M. F. Willson. 2001. Predator abundance and predation of artificial nests in natural and anthropogenic coniferous forest edges in southeast Alaska. Journal of Field Ornithology $72: 136-149$.

Delibes, M., P. GaONA, AND P. Ferreras. 2001. Effects of an attractive sink leading into maladaptive habitat selection. American Naturalist 158:277-285.

ELLISON, W. G. 1990. The status and habitat of the Rusty Blackbird in Caledonia and Essex counties. Vermont Fish and Widlife Department, Woodstock, VT.

ERskine, A. J. 1992. Atlas of breeding birds of the Maritime Provinces. Nova Scotia Museum, Halifax, NS.

FLood, N. 1978. Rusty Blackbird, p. 476-477. In M. D. Cadman, P. F. J. Eagles and F. M. Helleiner [EDS.], Atlas of the breeding birds of Ontario. University of Waterloo Press, Waterloo, ON.

Gates, J. E., AND L. W. Gysel. 1978. Avian nest dispersion and fledging success in field-forest ecotones. Ecology 59:871-883. 
Gill, J., K. Norris, P. Potts, T. Gunnarsson, P. Atkinson, And W. J. SuthERLAND. 2001. The buffer effect and large-scale population regulation in migratory birds. Nature 142:436-438.

Greenberg, R., And S. Droege. 1999. On the decline of the Rusty Blackbird and the use of ornithological literature to document long-term population trends. Conservation Biology 13:553-559.

Greenberg, R., D. W. Demarest, S. M. Matsuoka, C. MettkeHofmann, M. L. Avery, P. J. Blancher, D. C. Evers, P. B. Hamel, K. A. Hobson, J. Luscier, D. K. Niven, L. L. Powell, AND D. SHAw. In press. Understanding declines in Rusty Blackbirds. Studies in Avian Biology.

Griffith, D. M., AND C. L. Alerich. 1996. Forest statistics for Maine-1995. U.S. Department of Agriculture Forest Service Research Bulletin NE-135.

HARdY, Y. J., A. LAFOND, AND L. HAMEL. 1983. The epidemiology of the current spruce budworm outbreak in Quebec. Forest Science 29:715-725.

IRLAND, L. C. 1988. The spruce budworm outbreak in Maine in the 1970's: assessments and directions for the future. Maine Agricultural Experiment Station Bulletin 819.

James, F. C., AND H. H. SHUGART. 1970. A quantitative method of habitat description. Audubon Field Notes 24:727-735.

JoHNSON, C. A., AND R. J. NAIMAN. 1990. Browse selection by beaver: effects on riparian forest composition. Canadian Journal of Forest Restoration 20:1036-1043.

KenNARD, F. H. 1920. Notes on the breeding habits of the Rusty Blackbird in northern New England. Auk 37:412-422.

Klett, A. T., H. F. Duebbert, C. A. FaAnes, and K. F. Higgins, 1986. Techniques for studying nest success of ducks in upland habitats in the prairie pothole region. U.S. Fish and Wildlife Service Resource Publication 158.

KLUYVER, H. N., AND L. TinBERGEN. 1953. Territory and regulation of density in titmice. Archives Néerlandaises de Zoologie 10:265289.

KOKKO, H., AND W. J. SUTHERLAND. 2001. Ecological traps in changing environments: ecological and evolutionary consequences of a behaviourally mediated Allee effect. Evolutionary Ecology Research 3:537-551.

Laughlin, S. B., AND D. P. KibBe. 1985. The atlas of breeding birds of Vermont. University Press of New England, Hanover, NH

Lloyd, J. D., AND T. E. Martin. 2005. Reproductive success of Chestnut-collared Longspurs in native and exotic grassland. Condor 107:363-374.

LOKEMOEN, J. T. 1996. Using candlers to determine the incubation stage of passerine eggs. Journal of Field Ornithology 67:660-668.

Maine Forest Service [ONLINE]. 1999. State of the forest and recommendations for forest sustainability standards. http://www. maine.gov/doc/mfs/pubs/pdf/sofjun12.PDF (10 March 2000).

Martin, T. E. 1998. Are microhabitat preferences of coexisting species under selection and adaptive? Ecology 79:656-670.

Martin, T. E., AND G. R. Geupel. 1993. Nest-monitoring plots: methods for locating nests and monitoring nest success. Journal of Field Ornithology 64:507-519.

Matsuoka, S. M., D. Shaw, P. H. Sinclair, J. A. Johnson, R. M. Corcoran, N. C. Dau, P. M. Meyers, and N. A. Rojek. 2010 Nesting ecology of the Rusty Blackbird in Alaska and Canada. Condor 112:811-825.

Mcwilliams, W. H., B. J. Butler, L. E. CAldwell, D. M. Griffith, M. L. Hoppus, K. M. Lausten, A. J. Lister, T. W. Lister, J. W. Meltzer, R. S. Morin, S. A. Sader, L. B. Steward, J. R. Steinman, J. A. Westfall, D. A. Williams, A. Whitman, and C. W. WoODALL. 2005. The forests of Maine: 2003. U.S Department of Agriculture Forest Service Resource Bulletin NE-164.

Niven, D. K., J. R. SAUer, G. S. Butcher AND W. A. Link. 2004 Christmas Bird Count provides insights into population change in land birds that breed in the boreal forest. American Birds $58: 10-20$.

O'CONNOR, R. J. 1981. Habitat correlates of bird distribution in British census plots. Studies in Avian Biology 6:533-537.

Paton, P. W. C. 1994. The effect of edge on avian nest success: how strong is the evidence? Conservation Biology 8:17-26.

Peterson, J. M. C. 1988. Rusty Blackbird, Euphagus carolinus. In R. F. Andrle and J. R. Carroll [EDS.], The atlas of breeding birds in New York state. Cornell Univ. Press, Ithaca, NY.

Powell, L. L. 2008. Habitat occupancy, status, and reproductive ecology of Rusty Blackbirds in New England. M.Sc. Thesis, University of Maine, Orono, ME.

Powell, L. L., T. P. Hodgman, And W. E. Glanz. 2010. Home ranges of Rusty Blackbirds breeding in wetlands: How much would buffers from timber harvest protect habitat? 2010. Condor 112:835-841.

Powell, L. L., T. P. Hodgman, W. E. Glanz, J. D. Osenton, and D M. ELLIS. In press. A loose colony of Rusty Blackbirds nesting in northern Maine. Northeastern Naturalist.

R Development Core Team. 2008. R version 2.6.2: a language and environment for statistical computing. R Foundation for Statistical Computing, Vienna, Austria. http://www.R-project.org.

Remes, V. 2003. Effects of exotic habitat on nesting success, territory defense and settlement patterns in the Blackcap (Sylvia atricapilla). Conservation Biology 17:1127-1133.

RichARDS, T. 1995. Rusty Blackbird. Euphagus carolinus, p. 344 345. In C. R. Foss [ED.], The atlas of breeding birds of New Hampshire. Chalford, Dover, NH.

Robertson, B. A., AND R. A. Hutto. 2006. A framework for understanding ecological traps and an evaluation of existing evidence. Ecology 87:1075-1085.

ROBERTSON, B. A., AND R. L. HUtTO. 2007. Is selectively harvested forest an ecological trap for Olive-sided Flycatchers? Condor 109:109-121.

Robinson, S. K., F. R. Thompson, T. M. Donovan, D. R. WhiteHEAD, AND J. FAABORG. 1995. Regional forest fragmentation and the nesting success for migratory birds. Science 267:1987-1990.

RUDNICKY, T. C., AND M. L. HUNTER. 1993. Avian nest predation in clearcuts, forests, and edges in a forest-dominated landscape. Journal of Wildlife Management 57:358-364.

Sauer, J. R., J. E. Hines, AND J. Fallon [online]. 2005. The North American Breeding Bird Survey, results and analysis 1966-2005, version 6.2.2006. <http://www.mbr-pwrc.usgs.gov/bbs/bbs.html> (June 2007).

Sekercioglu, C. H., S. R. Loarie, F. Oviedo Brenes, P. R. Ehrlich, AND G. C. DAILY. 2007. Persistence of forest birds in the Costa Rican agricultural countryside. Conservation Biology 21:482-494.

Sergio, F., And I. Newton. 2003. Occupancy as a measure of territory quality. Journal of Animal Ecology 72: 857-865.

SHERRY, T. W., AND R. T. Holmes. 1988. Habitat selection by breeding American Redstarts in response to a dominant competitor, the Least Flycatcher. Auk 96:350-364.

Small, M. F., AND M. L. Hunter. 1988. Forest fragmentation and avian nest predation in forested landscapes. Oecologia 76: 62-64.

VAN HoRne, B. 1983. Density as misleading indicator of habitat quality. Journal of Wildlife Management 47:893-901.

Vander Haegen, W. M., and R. M. Degraaf. 1996. Predation on artificial nests in forested riparian buffer strips. Journal of Wildlife Management 60:542-550.

WELDON, A. J., AND N. M. HADDAD. 2005. The effects of patch shape on Indigo Buntings: evidence for an ecological trap. Ecology 86:1422-1431.

White, G. C., AND K. P. Burnham. 1999. Program MARK: survival estimation from populations of marked animals. Bird Study 46 Supplement:120-138. 